\title{
KEARIFAN LOKAL DALAM CERITA RAKYAT SEBAGAI MEDIA PENDIDIKAN KARAKTER UNTUK MEMBENTUK LITERASI MORAL SISWA
}

\author{
Gegana Jayapada*, Faisol, Binti Mariatul Kiptiyah \\ Universitas Negeri Malang
}

\section{A R T I K E L}

Kata Kunci:

Kearifan lokal

Cerita rakyat

Literasi

\begin{abstract}
A B S T R A K
Penurunan kualitas moral tengah menjangkiti siswa. Salah satu upaya untuk mengatasi krisis moral ialah mengoptimalkan bidang pendidikan, khususnya pembelajaran cerita rakyat. Cerita rakyat mengandung kearifan lokal dan nilai-nilai moral yang baik untuk siswa sehingga dapat dimanfaatkan sebagai media pendidikan karakter. Untuk membentuk literasi moral pada siswa, seorang guru harus menyajikan pembelajaran dengan empat tahapan, yaitu (1) tebak sifat, (2) kontrol diri, (3) pecah kasus, dan (4) ungkap rasa.
\end{abstract}

(C) 2017 BIBLIOTIKA Journal. All rights reserved

\section{PENDAHULUAN}

Dewasa ini penurunan kualitas moral tengah menjangkiti siswa di Indonesia. Perilaku-perilaku seperti kebiasaan bolos sekolah, merokok, mencuri, melawan guru, berkelahi dan tidak patuh pada orang tua tidak sepantasnya dilakukan oleh siswa. Menurut Patinus, Parwadi, dan Donatianus (2014:1) kondisi demikian terjadi juga di kalangan siswa-siswi SMP Negeri 07 Sengah Temila Kecamatan Sengah Temila Kabupaten Landak. Fakta-fakta tersebut tentu sangat memprihatinkan, padahal bangsa Indonesia terkenal sebagai bangsa yang beretika dan berbudi luhur. Bangsa Indonesia memiliki nilai-nilai karakter yang tercermin dari tradisi dan adat istiadat yang dianut masyarakatnya hingga saat ini. Nilai-nilai inilah dalam lokalitas setempat menjadi landasan moral sebagai pedoman hidup di masyarakat.

Salah satu upaya untuk mengatasi merosotnya moral siswa ialah mengoptimalkan bidang pendidikan. Pendidikan karakter dapat diajarkan secara terpadu melalui semua mata pelajaran termasuk mata pelajaran bahasa Indonesia. Mata pelajaran bahasa Indonesia dapat menjadi pintu masuk dalam penanaman nilai-nilai kearifan lokal, khusunya pada materi cerita rakyat. Menurut Amir (2013:21-22) cerita rakyat menyimpan kearifan lokal, kecendekian tradisional, pesan-pesan moral, dan nilai sosial dan budaya. Oleh karena itu, cerita rakyat dapat menjadi sarana komunikasi untuk membentuk karakter siswa, karena memuat pesan-pesan moral sesuai konteks sosial, agama, dan lingkungan masyarakat Indonesia.

Melalui pembelajaran cerita rakyat, siswa dilatih untuk meningkatkan kepekaan empatinya dengan meneladani pesan moral yang tergambar pada setiap karakter tokoh. Akan tetapi, dikhawatirkan pesan-pesan moral yang didapat oleh siswa hilang seketika bila hanya membaca cerita rakyat saja. Oleh karena itu, siswa perlu menuangkan pesan-pesan moral yang didapatnya dari cerita rakyat ke dalam bentuk tulisan. Upaya semacam ini dilakukan agar siswa meningkatkan tingkat kemahirwacanaan atau literasi.

Literasi pada dasarnya ialah kemampuan membaca, berpikir, dan menulis. Sebagaimana pendapat Soeyono (2011:3) yang menyatakan literasi adalah kegiatan membaca-berpikir-menulis. Penerapan literasi dalam pembelajaran cerita rakyat yakni siswa membaca cerita rakyat dalam upaya memahami nilai-nilai moral. Selanjutnya, siswa diajak untuk melakukan kegiatan menulis. Melalui makalah ini penulis bertujuan untuk menyajikan sebuah alternatif pembelajaran cerita rakyat dengan menggali kearifan lokal untuk membentuk literasi moral untuk siswa SMP.

\section{KEARIFAN LOKAL DALAM CERITA RAKYAT}

Kearifan lokal dalam bahasa asing sering disebut sebagai local wisdom. Secara etimologi, istilah wisdom dapat diartikan sebagai 'kearifan atau kebijaksanaan', sedangkan lokal secara spesifik menunjuk pada suatu daerah

\footnotetext{
${ }^{*}$ Corresponding author.

E-mail addresses: geganajayapada7@gmail.com (Gegana Jayapada), faisol3012@gmail.com (Faisol), bintimaria@gmail.com (Binti Mariatul Kiptiyah)
} 
setempat. Dalam pengertian ini, kearifan lokal (local wisdom) dapat dipahami sebagai kemampuan seseorang dalam berperilaku atau bersikap dengan menggunakan akal budinya di daerah setempat. Sejalan dengan Ridwan (2007:2-3) yang mengatakan kearifan lokal atau sering disebut local wisdom dapat dipahami sebagai usaha manusia dengan menggunakan akal budinya (kognisi) untuk bertindak dan bersikap terhadap sesuatu, objek, atau peristiwa yang terjadi dalam ruang tertentu. Nilai kearifan lokal sangat khas dan melekat di suatu masyarakat, sebab melalui proses panjang sejak keberadaan suatu masyarakat.

Cerita rakyat merupakan cerita yang berasal dan berkembang di masyarakat. Sebagaimana pendapat Nurgiyantoro (2010:165) yang menyatakan cerita rakyat adalah cerita yang berasal dari masyarakat dan berkembang secara turun temurun dalam masyarakat pada masa lampau sebagai sarana untuk memberikan pesan moral. Cerita ini juga diwariskan secara turun temurun melalui bahasa lisan. Sebagaimana pendapat Danandjaja (2002:50) yang menyatakan bahwa cerita rakyat adalah bentuk penuturan cerita yang pada dasarnya tersebar secara lisan dan diwariskan turuntemurun dari kalangan masyarakat pendukungnya secara tradisional. Jadi, dapat disimpulkan bahwa cerita rakyat merupakan cerita yang berasal dan berkembang di masyarakat diwariskan secara turun temurun melalui tuturan lisan.

Di samping itu, cerita rakyat menjadi cerita yang melekat di benak masyarakat. Di tengah-tengah masyarakat Indonesia, terdapat berbagai cerita rakyat yag menjadi alat penyampai pesan-pesan moral di berbagai daerah. Misalnya, Keong Emas dari Jawa Timur, Malin Kundang dari Sumatera Barat, dan sebagainya. Cerita-cerita rakyat tersebut mengandung nilai-nilai kearifan lokal yang dapat digunakan sebagai alat untuk mendidik anak menjadi insan yang cerdas, mulia dan bermartabat. Hal itu dapat dilihat pada pesan-pesan moral yang terkandung di dalamnya. Sebagaimana pendapat Suryani (2016:tanpa halaman) yang menyatakan nilai moral Cerita Rakyat Keong Emas terdapat dua nilai moral, yaitu nilai moral kejujuran dan nilai moral kesetiaan. Dengan demikian, cerita Keong Emas dapat menjadi sarana untuk mendidik anak. Kearifan lokal yang dapat digali dari cerita Keong Emas dari ungkapan Jawa yang menggambarkan sifat yang rajin bekerja tanpa mengharap imbalan, adalah "sepi ing pamrih rame ing gawe" (Widuroyekti, 2012:35).

\section{CERITA RAKYAT SEBAGAI MEDIA PEMBENTUKAN KARAKTER}

Sastra dapat dimanfaatkan sebagai media pembentukan karakter. Menurut Kanzunnudin (2012:202), sastra sebagai media katarsis dalam pembelajaran sastra dapat dimanfaatkan secara reseptif (bersifat menerima) dan ekspresif (kemampuan mengungkapkan) dalam pendidikan karakter. Pemanfaatan secara reseptif karya sastra sebagai media pendidikan karakter dilakukan dengan dua langkah yaitu (1) pemilihan bahan ajar, dan (2) pengelolaan proses pembelajaran, sedangkan pemanfaat secara ekspresif karya sastra sebagai media pendidikan karakter dapat ditempuh melalui jalan mengelola emosi, perasaan, semangat, pemikiran, ide, gagasan dan pandangan siswa ke dalam bentuk kreativitas menulis karya sastra dan bermain drama, teater, atau film. Sebagai suatu genre sastra, cerita rakyat dapat dimanfaatkan sebagai media pembentukan karakter secara reseptif maupun ekspresif. Uraian pemanfaatan cerita rakyat sebagai media pembentukan karakter, disajikan sebagai berikut.

Pertama, pemanfaatan secara reseptif. Pertama-tama, guru harus memilih cerita rakyat. Cerita rakyat yang dipilih sebagai bahan ajar adalah cerita rakyat yang baik secara estetis dan etis. Hal itu dapat dilihat dari konstruksi struktur sastranya dan kandungan nilai-nilai yang dapat membimbing siswa menjadi pribadi yang baik. Langkah berikutnya adalah pengelolaan proses pembelajaran. Dalam pengelolaan proses pembelajaran, guru harus mampu mengarahkan siswa dalam proses membaca cerita rakyat. Selanjutnya, siswa diarahkan untuk dapat menemukan nilainilai moral dari cerita rakyat yang dibacanya. Guru tidak boleh membebaskan siswa untuk menemukan dan menyimpulkan sendiri nilai-nilai moral yang terdapat dalam cerita rakyat. Selanjutnya, guru membimbing siswa untuk dapat menerapkan nilai-nilai moral dalam kehidupan sehari-hari yang didapatnya dari cerita rakyat.

Kedua, pemanfaatan secara ekspresif. Guru membimbing siswa untuk mengelola emosi, perasaan, pendapat, ide, gagasan, dan pandangan untuk diinternalisasi dalam diri kemudian dituangkan ke dalam cerita rakyat. Emosi, perasaan, ketidakpuasan terhadap suatu sistem yang berlaku, rasa marah ingin berdemontrasi, dan sejenisnya terhadap sesuatu hal dapat diaktualisasikan dalam pembelajaran cerita rakyat, misalnya, bermain drama.

\section{LITERASI DALAM PEMBELAJARAN CERITA RAKYAT}

Dalam Kurikulum 2013 dijelaskan bahwa bahasa adalah penghela ilmu pengetahuan. Dengan demikian, bahasa menjadi sarana penyampai informasi. Oleh karena itu, siswa harus menguasai kemampuan berbahasa untuk menguasai mata pelajaran lain.

Bahasa Indonesia memiliki peran penting untuk diajakarkan, sebab berfungsi sebagai bahasa nasional dan bahasa negara. Sebagaimana Subandiyah (2015:113) yang menyatakan pengajaran bahasa Indonesia yang berfungsi sebagai bahasa nasional dan bahasa negara, memiliki dua peran penting dalam Kurikulum yaitu (1) meningkatkan penguasaan berbahasa, dan (2) membentuk kompetensi literasi. Pertama, melalui pembelajaran dapat ditingkatkan kemampuan siswa dalam berbahasa seperti menyimak, membaca, menulis, dan berbicara. Kedua, membaca dan menulis dibutuhkan untuk menguasai bermacam pengetahuan yang terdapat dalam mata pelajaran lain.

Pada dasarnya semua mata pelajaran bertujuan untuk menanamkan pengetahuan kepada siswa. Pengetahuan diperoleh siswa dari kegiatan reseptif (membaca atau menyimak), sehingga siswa memperoleh sejumlah informasi dari berbagai sumber. Untuk mengasah kreativitas siswa dari sejumlah informasi yang didapatnya, maka perlu dilakukan kegiatan produkti (menulis atau berbicara). Dengan kata lain, kemampuan siswa juga ditentukan oleh kemampuan literasi.

Literasi merupakan serangkaian tiga kegiatan, yaitu membaca, berpikir, dan menulis. Sebagaimana pendapat Soeyono (2011:3) yang menyatakan literasi adalah kegiatan membaca-berpikir-menulis. Menurut Mahsun (dalam 
Kemendikbud, 2016) bahwa kegiatan literasi tidak hanya membaca, tetapi juga dilengkapi kegiatan yang harus dilandasi dengan keterampilan untuk mengubah meringkas, memodifikasi, menceritakan kembali. Oleh karena itu, penerapan literasi dalam pembelajaran cerita rakyat, yaitu (1) siswa diminta untuk membaca cerita rakyat dan (2) siswa diajak untuk menulis.

\section{MEMBENTUK LITERASI MORAL MELALUI PEMBELAJARAN CERITA RAKYAT}

Dalam makalah ini cerita rakyat dimanfaatkan sebagai media pendidikan karakter secara reseptif maupun ekspresif. Untuk membelajarkan cerita rakyat, seorang guru harus mampu membuat siswa menyenangi cerita rakyat terlebih dahulu. Caranya dengan mengenalkan contoh-contoh cerita rakyat dari berbagai daerah. Dengan demikian, siswa tentu akan melihat kekayaan warisan nusantara, sehingga hal ini akan menimbulkan rasa nasionalisme. Selanjutnya, siswa dilatih untuk menentukan nilai-nilai moral dari cerita rakyat yang diajarkan. Dengan memahami nilai-nilai moral dari cerita rakyat, siswa diharapkan menemukan kebenaran di masyarakat. Secara rinci, tahapan pembelajaran cerita rakyat mengadopsi Wachidah (2017:12). Tahapan pembelajaran yang dilakukan terbagi menjadi empat tahap, yaitu (1) tebak sifat, (2) kontrol diri, (3) pecah kasus, dan (4) ungkap rasa. Keempat tahapan ini dijelaskan sebagai berkut.

Pertama, tebak sifat. Pada tahap ini siswa disuruh menemukan nilai-nilai moral yang terkandung dalam cerita rakyat melalui tokohnya-tokohnya. Kedua, latihan kontrol diri. Pada tahap ini guru menyajikan gambaran diri siswa yang disesuaikan dengan sifat tokoh dalam cerita rakyat. Selanjutnya, siswa memilih salah satu tokoh yang mampu menggambarkan dirinya.

Ketiga, pecah kasus. Pada tahap ini siswa disuruh memerankan tokoh dalam cerita rakyat di depan kelas, lalu mereka memecahkan kasus dalam cerita tersebut. Selanjutnya, siswa merefleksikan pada dirinya masing-masing terkait nilai moral yang baru saja didapatnya. Keempat, ungkap rasa. Pada tahap ini siswa diberi kesempatan untuk mengungkapkan perasaannya setelah menonton pemeranan yang dilakukan temannya tadi. Selanjutnya, siswa mengungkapkan perasaannya ke dalam bentuk tulisan.

\section{PENUTUP}

Kearifan lokal dapat dimanfaatkan sebagai media pendidikan karakter untuk siswa di sekolah. Nilai-nilai kearifan lokal dapat membuat siswa menjadi manusia yang baik dalam kehidupan bermasyarakat. Cerita rakyat dalam pembelajaran berfungsi sebagai media katarsis dalam pembelajaran sastra dapat dimanfaatkan secara reseptif (bersifat menerima) dan ekspresif (kemampuan mengungkapkan) dalam pendidikan karakter. Dalam membentuk moral siswa, siswa perlu diajak membaca cerita rakyat dalam rangka mencari nilai-nilai moral, namun dikhawatirkan pesan-pesan moral yang didapat oleh siswa hilang seketika bila hanya membaca cerita rakyat saja. Melalui kegiatan menulis, siswa dapat menuangkan pesan-pesan moral yang didapatnya dari cerita rakyat ke dalam bentuk tulisan. Secara rinci, tahapan pembelajaran cerita rakyat yang dilakukan oleh guru terbagi menjadi empat tahap, yaitu (1) tebak sifat, (2) kontrol diri, (3) pecah kasus, dan (4) ungkap rasa.

\section{DAFTAR RUJUKAN}

Amir, Andriyetti. 2013. Sastra Lisan Indonesia. Yogjakarta: CV Andi Offset.

Danandjaja, J. 2007. Folklor Indonesia, Ilmu Gosip, Dongeng, dan Lain-lain. Jakarta: Pustaka Utama Grafiti

Kemendikbud. 2016. Direktorat Jenderal Pendidikan Dasar dan Menengah. (Online), http://dikdas.kemdikbud.go.id, diakses tanggal 18 Oktober 2017.

Nurgiyantoro, $\quad$ B. 2010. Sastra Anak: Pengantar Pemahaman Dunia Anak. Jogjakarta: Gajah Mada University Press.

Ridwan, Norma. 2007. "Landasan Keilmuan Kearifan Lokal". Makalah dalam Jurnal Studi Islam dan Budaya Ibda' .Vol. 5. No. 1. Jan-Jun 2007. Hlm. 27-38

Soeyono. 2011. Pembelajaran Efektif dan Produktif Berbasis Literasi. Malang: Cakrawala Indonesia.

Subandiyah, Heny. 2015 Pembelajaran Literasi dalam Mata Pelajaran Bahasa Indonesia. Paramasastra Jurnal Ilmiah Bahasa Sastra dan Pembelajarannya, (Online), 2 (1) :111-123, (http://ejournal.fbs.unesa.ac.id/index.php/Paramasastra/article/download/27/32), diakses 6 Oktober 2017.

Widurojekti, Barokah. 2012. Kearifan Lokal dalam Sastra Lisan sebagai Materi Pembelajaran Karakter Di Sekolah Dasar

Patinus, Parwadi, Redatin, BSEP, Donatianus. 2014. Kenakalan Remaja di Kalangan Siswa-Siswi Smpn 07 Sengah Temila Kecamatan Sengah Temila Kabupaten Landak. Jurnal Tesis PMIS-UNTAN-PSS-2014, (Online), (https://media.neliti.com/media/publications/9529-ID-kenakalan-remaja-di-kalangan-siswa-siswi-smpn-07sengah-temila-kecamatan-sengah.pdf), diakses 20 Oktober 2017. 